\title{
Lexis
}

Journal in English Lexicology

18 | 2021

Lexical learning and teaching

\section{Dictogloss steals the show? Productive use of formulaic sequences by advanced learners}

\section{Magdalena Zinkgraf and María Angélica Verdú}

\section{(2) OpenEdition}

1 Journals

\section{Electronic version}

URL: https://journals.openedition.org/lexis/6079

DOI: $10.4000 /$ lexis.6079

ISSN: 1951-6215

\section{Publisher}

Université Jean Moulin - Lyon 3

\section{Electronic reference}

Magdalena Zinkgraf and María Angélica Verdú, "Dictogloss steals the show? Productive use of formulaic sequences by advanced learners", Lexis [Online], 18 | 2021, Online since 18 December 2021, connection on 21 December 2021. URL: http://journals.openedition.org/lexis/6079 ; DOI: https:// doi.org/10.4000/lexis. 6079

This text was automatically generated on 21 December 2021.

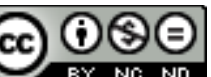

Lexis is licensed under a Creative Commons Attribution-NonCommercial-NoDerivatives 4.0 International License. 


\title{
Dictogloss steals the show? Productive use of formulaic sequences by advanced learners
}

\author{
Magdalena Zinkgraf and María Angélica Verdú
}

We would like to thank Secretaría de Ciencia y Técnica from Universidad Nacional del Comahue, which subsidises Research Project J033, the results of which this article presents.

\section{Introduction}

Descriptions of language like the generative paradigm view language as "a set of syntactic rules and and a set of lexical items and the syntactic rules provide and determine the slots that lexical items can fit" (Gheitasi [2017:15]). According to this description, users of a language insert lexical units into the slots the grammatical system allows (Selivan [2018:3]). Over the last few decades, however, corpus studies into the nature of language and the interrelationship between grammar and lexis have highlighted the pervasiveness of recurrent strings of words, and their importance in the construction of meaning. Applied Linguistics is, as a result, experiencing a shift towards the teaching of formulaic language as an essential part of foreign language vocabulary instruction. This article presents the results of a study carried out in a university EFL context with advanced Spanish-speaking students of English, which was designed to explore the effects of two explicit-instruction treatments on long-term formulaic sequence acquisition. The study focuses on participants' spontaneous, uncued use of nine selected sequences across different written assignments submitted throughout an academic term. After a brief review of the scientific literature on the impact of vocabulary-focused instruction on formulaic sequence acquisition, and particularly on EFL learners' productive formulaic sequence use in written tasks, we will describe the study in terms of participants, experimental groups and conditions, data-collection instruments and data analysis as well as the criteria for the selection of the target sequences. Results for both experimental groups and the control group are 
presented across data collection instances over time, and analysed in terms of recurrence and participants' retention of and attrition in the selected sequences longitudinally. The discussion of these findings will focus on the potential advantages of dictogloss-based instruction for long-term acquisition of formulaic sequences by advanced EFL learners. Some implications from the study with respect to formulaic language teaching and learning will also be discussed. Most studies into the acquisition of formulaic sequences collect evidence of learners' uptake no later than four weeks after the period of instruction, and Wulff [2019] highlights the need in FS acquisition research for year-long investigations. The present study aims at addressing this gap, and explores the impact of FS-focused instruction, and of dictogloss in particular, on university students' acquisition of formulaic sequences during a longer time span.

\section{Theoretical framework}

2 Findings from corpus linguistics have led to what Greaves \& Warren [2010: 221] term the "reappraisal of the status of lexis", which has now been found to interact with grammar, and even to determine grammatical constructions in prefabricated chains of words. Corpus studies have brought into focus the recurrence of these strings of words typically used to convey the same meanings across text types and genres. According to different theoretical approaches, various terms - such as multiword units, phrases, phraseologisms, formulas, formulae and lexical bundles - have been used to refer to these multiword sequences. In this article, we will adopt Wray's definition of 'formulaic sequences' (FSs): “a sequence, continuous or discontinuous, of words [...] stored and retrieved whole from memory at the time of use, rather than being subject to generation or analysis by the language grammar" [2002: 9]. Some examples of these sequences in Selivan [2018: 1] are "at all costs", "see you later", "as the study suggests" and "come to think of it". They each perform different communicative functions and have specific meanings known to native speakers of a language.

In the lexicon of each L1 speaker these word strings are retrieved as wholes from memory and recognized and produced as part of their repertoire. L2 learners are usually not aware of the pervasiveness of these phrases in the target language and due to traditional single-word teaching approaches to vocabulary - concentrate on learning isolated lexical items, at least in the early stages of acquisition (Conzett [2000] in Timmis [2015]). Studies in spoken and written L2 language use show that the L2 lexicon contains far fewer formulaic sequences than that of L1 speakers. When foreign language (FL) learners use formulaic sequences in the target language, they do so much more frequently than L1 speakers would and in contexts where native speakers would not (Alhassan \& Wood [2015], Peters \& Pauwels [2015]).

4 Research (with English as the target FL) by Boers et al. [2006], Eyckmans [2007], Stengers [2009] and Wray \& Fitzpatrick [2008] suggests that good command of these phrases, of their typical occurrence and of their use restrictions contributes to learners' fluency (Wood [2009]; Conklin \& Schmitt [2008]; Li \& Schmitt [2010]), and constitutes evidence of a high level of proficiency. However, Lewis [2009] and Wiktorsson [2003], among others, have shown that even advanced university-level EFL learners encounter numerous difficulties with a native-like level of formulaicity in written production. Pedagogical approaches should therefore aim at fostering learners' 
familiarity with FS use, and ensuring abundant opportunities for exposure to and practice of these frequent patterns in language.

5 Boers \& Lindstromberg [2012] and Mueller [2017] argue that explicit FS instruction accompanied by awareness-raising tasks yield significant learning gains in EFL contexts. Pellicer-Sánchez \& Boers [2019] also describe the effectiveness of instructional procedures which are semi-incidental, directing learners' attention to the strings in the input as favourable conditions for FS learning. Different chunk-focusing approaches have been implemented to assess the impact of FS-focused explicit instruction on L2 learners' vocabulary acquisition, as measured in their written production (Wood [2010]; Jones \& Haywood [2004]). Thornbury [2019] highlights the awareness-raising approach (Lewis [1997]) and the analytic approach put forward by Boers \& Lindstromberg [2009] as two means of implementing a pedagogical focus on FSs. Both approaches draw on focus-on-form techniques (Doughty \& Williams [1998]), traditionally used to focus on grammatical features, and which draw learners' attention to target aspects of vocabulary, such as formulaic sequences. "Input flood" ensures greater exposure to target sequences through a variety of tasks and contexts, and "input enhancement" grants visual saliency to the sequences through the use of bold type, underlining or highlighting.

6 As a pushed-output procedure, Wajnryb's dictogloss or grammar dictation [1990] has also recently been adapted in FS-focused instruction. This technique consists of the dictation of a text - containing target FSs - at normal speaking speed while learners take notes. The text is read out four or more times but learners are not given enough time to take dictation. At a subsequent group stage, they write a text that expresses the same meanings as the original. Finally, the different texts reconstructed by the groups are compared to select the one that best conveys the ideas in the original text (Wajnryb [1990]).

7 In Vasiljevic [2010] this technique is described in detail especially as a means to teach listening comprehension by exploiting its collaborative nature. The main advantages of dictogloss are also outlined: learners profit from the reconstruction stage since they get to use the target language element in focus, they engage in genuine communication in an attempt to reach the goal (the reconstructed text) while at the same time they have been exposed to three readings of a text that contains a certain linguistic feature which is focused on.

8 Studies like those reported in Janssens [2016] and Lindstromberg, Eyckmans \& Connabeer [2016] explore the impact of dictogloss on FS acquisition by university learners. These studies compare the implementation of the standard dictogloss and a modified dictogloss procedure in an English-for-Academic-Purposes context to assess FS use in both group and individual text reconstructions. The modified dictogloss offered participants the target sequences in the line and section of the text where they appeared in the original text (an abstract). Their findings indicate that in the modified procedure participants used more target sequences than did those in the standard one. Janssens [2016] replicates this study and in it the modified dictogloss includes the first letter of each word in the target sequences, rather than the whole phrases. Results obtained through post dictogloss text reconstruction indicate that the experimental group (modified procedure) did not produce more FSs than the standard dictogloss group. In both conditions, participants were able to recall fewer than a third of the 
target sequences one week after the treatment. FS use in these two studies was not spontaneous or uncued.

Little empirical research has documented general FS acquisition longitudinally, and in the few cases where it has, as in Le-Thi et al. [2017], and Peters \& Pauwels [2015], delayed data-collection instruments occur no later than four to six weeks post intervention. Additionally, these studies collect no data on spontaneous FS use in writing. In his study on attrition and retention of formulaic sequences in EFL university learners, Alharthi [2015] takes the first step towards collecting empirical data on FS acquisition in a longitudinal study involving discrete-item posttests and delayed posttests after the summer recess. Participants in his study were tested on formulaic sequences that were assumed to have been known by learners or focused on in previous course materials. The pretest and posttest consisted of both recall and recognition tasks to determine which aspect of FS knowledge was more affected by attrition over time. The recall task consisted of a c-test where test-takers had to complete the gapped formulaic sequence for which the first letters were provided. Alharthi's [2015] findings show greater attrition in recall (productive knowledge) than in recognition, which he attributes to "the common perception among researchers (Aitchison, [1994]; Crow, [1986] and Schmitt, [2014]), which has repeatedly shown that recall knowledge of meaning is susceptible to attrition more than recognition knowledge of meaning" (Alharthi [2015: 238]). Predictably, attrition appears to affect recall of more opaque FSs than of transparent ones. In this study, however, spontaneous production is not measured.

10 This synthesis of previous research indicates a gap in studies of vocabulary-focused instruction in advanced university settings, where evidence of spontaneous, uncued production of focused FSs over a substantial amount of time (more than four weeks) is lacking. The present study aims to address the challenge of gathering longitudinal data probing the effects of different types of FS-focused instruction on the productive knowledge of formulaic sequences in EFL. This productive knowledge will be measured through participants' autonomous FS use in writing tasks.

\section{Description of the study}

11 An experimental study was designed to teach nine formulaic sequences through two types of treatment conditions, and explore the effects of instruction on the acquisition of formulaic sequences over time. Advanced university EFL learners' uptake of these sequences was measured through cued-output tests (immediate and delayed), and spontaneous FS use in their written production ${ }^{2}$. Due to space limitation, the present paper will not provide an analysis of this data, but we will concentrate instead on uncued FS use across time, by three learner groups. The following subsections will provide details on participants and their groups, the types of activities carried out by the groups, the protocols followed in each case, data collection instruments and their analysis.

\subsection{Participants}

Three cohorts (37 participants in all) of C1 (CEFR) Spanish-speaking university students participated in the study while taking English Language Level III in the Teacher-training 
programme at the School of Languages, Comahue University, Argentina ${ }^{3}$. Ages for the participants in the study ranged from 20 to 34 . To preserve the ecology of the different groups, each treatment condition was implemented at different times in the cohort's academic year, depending on when the topic including the text with the target FSs was planned for. Group $1(n=13)$ took part in the experiment in the second half of 2015, the Control Group ( $n=7)$ in the first term of 2016 and Group $2(n=17)$ in the first half of 2017. Data was collected from a total of 37 learners, even though more learners were present in the courses and took part in the activities. Because some of these learners did not comply with all the requirements of attendance for the instruction and data collection instances, ten in Group 1, eight in Group 2, and three in the Control Group were discarded from the study and their data is not analysed here.

\subsection{Target sequences}

Twenty-three formulaic sequences appearing in a text in Objective Proficiency (Sharp \& Capell [2013: 16-17]) were considered as candidates for this study. The holistic nature of these FSs was established by checking them against entries in monolingual dictionaries and the Oxford Dictionary of Current Idiomatic English (ODCIE), and determining their frequency measure in COCA (Davies [2008-]) and in Google (as a general web corpus). To identify the target sequences learners were least familiar with, a c-test task was designed as a pretest. This test consisted of 23 sentence contexts for candidate FSs drawn from COCA (Davies [2008-]) or from the examples in English dictionaries, with blanks for the component elements of the sequences. C-tests are gap filling exercises where the initial letters of the words are offered as guidance for completion. An example item from the pretest is provided below (example 1), illustrating one of the candidate sequences which was later discarded as a target sequence, because it was already known by participants.

(1) There has been a lot of $h$ d surrounding the issue of global warming. [heated debate]

At the onset of the study and at the beginning of each course, all learners gave their written consent to be part of the experiment, and completed the pretest. In 2015 the results of the pretest determined which candidate FSs were the nine least known to learners, and these were selected to be taught through the instruction conditions in the experimental groups. They are presented in Table $1 .{ }^{4}$

Table 1. Selected target formulaic sequences

\begin{tabular}{|l|l|}
$\begin{array}{l}\text { 1. the prospect of } \\
\text { 2. outside the constraints of }\end{array}$ & $\begin{array}{l}\text { 6. cloud (my) appreciation of } \\
\text { 7. (be) at once (adjective) and (adjective with an opposite } \\
\text { meaning) } \\
\text { of }\end{array}$ \\
$\begin{array}{l}\text { 4. ignore at (someone's) peril } \\
\text { 5. (be) oblivious to something }\end{array}$ & \begin{tabular}{l} 
9. for all the good (something) did (them) \\
\hline
\end{tabular}
\end{tabular}




\subsection{Protocols and treatment}

The Control Group's instruction consisted of the same awareness-raising tasks as Group 1 and Group 2, with a total duration of one hour in all. As in Peters \& Pauwels [2015], the two experimental groups completed a common set of tasks (equivalent in number of hours of instruction) at the beginning of treatment, during which their attention was drawn to the target sequences. These were initial Tasks $1,2 a$ and $2 b$ (see Table 2). Later on, while Group 1 worked on gap-filling and focus-on-form oriented tasks (Tasks 3 to 7), with one instance of dictogloss, Group 2 exclusively carried out two dictogloss tasks, with text reconstruction and discussion.

The groups were successive cohorts co-taught by the same two teachers during 2015, 2016 and 2017. The teachers and authors of the present article were also in charge of data collection and analysis. Participants were not aware of which FSs were focused on during the study.

Table 2. Instruction periods, and activity types per group across weeks

\begin{tabular}{|c|c|c|c|c|c|c|}
\hline \multirow[b]{2}{*}{ WEEKS } & \multicolumn{2}{|c|}{ Control group } & \multicolumn{2}{|l|}{ Group 1} & \multicolumn{2}{|l|}{ Group 2} \\
\hline & $\begin{array}{l}\text { Activity } \\
\text { types }\end{array}$ & $\begin{array}{l}\text { Number of } \\
\text { instruction } \\
\text { hours }\end{array}$ & $\begin{array}{l}\text { Activity } \\
\text { types }\end{array}$ & $\begin{array}{l}\text { Number of } \\
\text { instruction } \\
\text { hours }\end{array}$ & $\begin{array}{l}\text { Activity } \\
\text { types }\end{array}$ & $\begin{array}{l}\text { Number of } \\
\text { instruction } \\
\text { hours }\end{array}$ \\
\hline Week 1 & $\begin{array}{l}\text { Task } 1 \\
\text { Task 2a } \\
\text { Task 2b }\end{array}$ & 1 & $\begin{array}{l}\text { Task } 1 \\
\text { Task 2a } \\
\text { Task 2b } \\
\text { Task } 3\end{array}$ & 2 & $\begin{array}{l}\text { Task } 1 \\
\text { Task 2a }\end{array}$ & 1 \\
\hline Week 2 & --- & & $\begin{array}{l}\text { Task } 4 \\
\text { Task } 5 \\
\text { Task } 6\end{array}$ & 1 & $\begin{array}{l}\text { Task } 2 \mathrm{~b} \\
\text { Dictogloss }+ \\
\text { discussion } 1\end{array}$ & $2 \frac{1}{2}$ \\
\hline Week 5 & --- & & $\begin{array}{l}\text { Task } 7 \\
\text { Dictogloss } 1\end{array}$ & 1 & Dictogloss 2 & 1 \\
\hline Week 7 & --- & & $\begin{array}{l}\text { Discussion, } \\
\text { Dictogloss } 1\end{array}$ & 1 & $\begin{array}{l}\text { Discussion } \\
\text { for } \\
\text { dictogloss } 2\end{array}$ & 1 \\
\hline $\begin{array}{l}\text { Hours, } \\
\text { total }\end{array}$ & & 1 & & 5 & & $51 / 2$ \\
\hline
\end{tabular}

The first two tasks which were common to all three learner groups consisted of an awareness-raising task, where learners were instructed to find the target sequences in the text and guess their meaning (Task 1), followed by a more elaborate task in which learners noticed the sequences in context and matched them with their definition (Task 2a) and then analysed their use in context (Task 2b). Participants were also encouraged to notice whether each expression was a verb phrase or prepositional 
phrase, for example, and they were also shown sequence boundaries (through use of boldface type).

The different treatments for Groups 1 and 2 are described below. What is being compared in these two conditions are activity types that foster retrieval from memory (Lindstromberg \& Boers [2008]): on the one hand, the dictogloss technique for Group 2 (as a means of focusing on and practising the selected formulaic sequences in context); and on the other, the mixed FS-focused tasks carried out by Group 1. The combination of activity types in Group 1 (Tasks 3 to 7) and the dictogloss tasks (Group 2) provided an equivalent number of exposures to the target sequences, receptive and productive practice, and retrieval from memory.

\subsubsection{Group 1 Treatment tasks}

Group 1 worked for four sessions (five hours) on the selected FSs through a set of seven awareness-raising and gap-filling tasks, together with one dictogloss (Wajnryb [1990]). The first two tasks this group completed are described above, and the specific tasks completed by Group 1 below. The procedure followed by Group 1 resembles that of the treatment group in Lindstromberg et al. [2016:13]. In these activities, participants' attention was drawn to the occurrence of the sequences in the contexts where they appeared, followed by a grammatical analysis of each sequence.

In Task 3, a gap-filling task, learners completed sentences with one of the target FSs, as shown in example 2:

(2) All new bookings made thereafter will be availability and rates at time of booking. [subject to]

Task 4, a c-test of three gapped sentences, offered learners three context sentences (needing completion) per target (example 3). The purpose of this task was to offer participants several examples where the target sequences occurred in natural L1 contexts. Boldface was used to highlight the boundaries of each target FS:

(3) a. And when we examine those repetitive media messages, we find those

[...] which may ultimately disinhibit by eroding the internalised constraints, and which we discard a o_-_-_ p_-_-_.

b. She stressed that the 'pernicious effect' of such a TV diet 'is a problem we ignore a o

c. Mourning can have a therapeutic function that we ignore a o. p . [at our peril]

Task 5 asked Group 1 participants to match nine sentence beginnings and endings, involving contextualised FS use. The sentence breaks occurred within the target FS, calling learners' attention to their components, as shown in example 4:

(4) "It will also free taxpayers' money from being unnecessarily tied up in an asset which has the prospect... [of becoming more profitable under privatisation".]

In Task 6, members of Group 1 wrote sentences of their own, with explicit instructions to include the target FSs in their sentences. This production activity was completed first individually, and then in small groups. Task 7 was a transformation exercise that our university learners are familiar with. Example 5 shows an item Group 1 students 
were to rewrite, using one of the target sequences (transforming the sentence, but maintaining its meaning). The items were drawn from dictionary examples or from corpora:

(5) In 2012 the US faced the possibility of a future nuclear program in Iran and an ongoing problem with North Korea.

In 2012 the US faced .................................................. and an ongoing problem with North Korea. [the prospect of a nuclear program in Iran]

Finally, Group 1 was asked to complete Dictogloss 1 Task (see the next section and Appendix $C$ for a more detailed description).

In all but the dictogloss task, the focus-on-form techniques of input flood (ensuring sufficient exposure to the target sequences) and input enhancement (through boldtype highlighting of FSs: Doughty \& Williams [1998]) draw learners' attention to the meaning, form, and use of the target FSs, as in examples 3 and 4, above. All tasks (Tasks 1 to 7 in Group 1 and Tasks 1 to 3 in Group 2) were completed first individually and then checked in small groups before carrying out a general checking phase with the whole class.

\subsubsection{The Dictogloss Task}

24 All dictogloss texts (See Appendix A \& B) were written to include instances of the nine target FSs, and were based on the use of these sequences in the course book; they also narrated anecdotes from the researchers' own experiences relating to travel and hobbies. In order to respect the typical contexts and restrictions of use for these sequences, the target FS sentences in the dictogloss texts imitated COCA examples for these sequences (Davies [2008-]), and were similar in length in terms of word and sentence numbers.

Group 2 was exposed to: a) the same initial awareness-raising tasks as Group 1; and b) two instances of FS-oriented dictogloss, spread across three sessions, totaling five and a half hours of instruction (see Table 2 above). Group 1's dictogloss text (Appendix A) was also used as dictogloss text 1 in Group 2.

The collaborative stage of text reconstruction in dictogloss - where participants discuss and reach a conclusion as to the best way to convey ideas from the original text - is similar to the small-group discussion carried out among Group 1 learners to share and check the answers for the c-test, matching and transformation tasks.

\subsection{Data collection}

Data produced by ten participants was discarded because they gave a correct answer in the cloze-test procedure for the majority of the 23 sequences in the pretest, which was evidence of prior knowledge of these sequences. If they had taken the course in the previous year, they would have undergone FS-focused instruction. This experience made them unsuitable for inclusion in the Group 2 data. Learners who did not complete two out of the three posttests were also removed from the study. Additionally, learners in Group 1 needed to have attended all three treatment sessions; participants in Group 2 also had to be present for both dictogloss tasks. To gain insights into more spontaneous (uncued) FS use, learners' essay writing tasks submitted as part of the course's requirements were analysed. 
As mentioned above, because the instruction period for Group 1 took place in the second academic term, only three essays per participant were collected, whereas the Control Group and Group 2's first-term treatment allowed for the analysis of ten essay tasks. To balance out the data collection instances in each experimental condition, only FS production in those writing assignments completed eight weeks after treatment was studied for all three groups. The application of this criterion resulted in the analysis of three assignments for Group 1 and five for Group 2 and the Control Group. Table 3 below presents the different writing activities completed by each of the groups during the eight weeks immediately following the treatment period.

Table 3. Data collection per group across time

\begin{tabular}{|l|l|l|l|}
\hline \multirow{2}{*}{ Post- instruction weeks } & \multicolumn{2}{|l|}{ Groups } \\
\cline { 2 - 4 } & Control group & Group 1 & Group 2 \\
\hline Week 9 & Writing activity A & Writing activity A & Writing activity A \\
\hline Week 10 & Writing activity B & & Writing activity B \\
\hline Week 11 & Writing activity C & & Writing activity C \\
\hline Week 12 & & Writing activity B & \\
\hline Week 13 & Writing activity D & & Writing activity D \\
\hline Week 14 & & & \\
\hline Week 15 & & & Writing activity E \\
\hline Week 16 & Writing activity E & & \\
\hline
\end{tabular}

The first writing activity (Writing activity A) - analysed for all three groups - took place in Week 9, once the instruction period was over (see Table 2). The writing tasks consisted of answers to a set of questions about a text (which did not contain further instances of the target formulaic sequences), and an essay of no more than 350 words. The writing activities were not specifically designed to foster the production of any of the nine target sequences. The essays were written in response to one of a set of five prompts (which did not contain the target FSs), related to the themes of the current course unit. For each writing activity, both tasks were completed during a three-hour time slot in class, without recourse to reference materials; each writing session generated about 500 words total. Each different writing activity (in Table 3) involved a different set of prompt options within and across groups.

\subsection{Data analysis}

29 A careful analysis of our learners' written production - focusing on the target FSs followed the completion of each data collection task. All handwritten and non-digital assignments produced by the participants in their course during data-collection weeks 
were analysed manually and checked independently by both researchers, in search of occurrences of the nine target FSs (or possible variants of each). FS uses were tallied per participant and per writing task. To preserve learner anonymity, participants were assigned a code number to be identified and to classify their production ${ }^{5}$. Attempted sequences - which did not conform to the conventional use of the target FSs - were recorded as "attempts", following Wiktorsson [2003] and Lewis [2009].

\section{Results and Discussion}

A word of caution needs to be issued with respect to the type of analysis that can be conducted with the relatively small number of FS instances collected. Production instances in this study do not allow for an extensive quantitative hypothesis-testing approach, since the number of participants in each group is small and disparate. The FS production measured in this paper is spontaneous and uncued, with no explicit instructions to use the target FSs in the writing activities. In some studies, researchers stipulate the use of target forms in tasks, but we decided to follow Coxhead's [2008] recommendation, to avoid influencing the production of the target sequences. For this reason, the number of sequences used is variable in this study. A descriptive analysis of the data is therefore in order - a type of data analysis that opens an interesting window onto individual learners' acquisition processes.

For Eisenbeiss [2010:2], data obtained through spontaneous production makes it "difficult to assess whether learners have acquired the forms or constructions under study". If they do not use the FSs in their writing activities, it cannot be claimed that they have not acquired them. Yet uncued occurrences - because they are unprompted are all the more indicative of developing formulaic competence. A general appraisal of all three groups' spontaneous production of the target sequences can help us understand FS-learning processes over a limited time span.

Table 4 presents correct FS productions and FS attempts for each of the three learner groups in our study. The rate of correct and attempted FSs produced (line 2) was calculated by dividing the number of FSs by the number of written assignments analysed per group (three writing tasks in Group 1, and five in Group 2 and the Control Group) across eight weeks post treatment. Column seven presents the difference in rates of FS production between Group 1 and Group 2.

Table 4. Rate and number of correct FSs and attempts, per group

\begin{tabular}{|l|l|l|l|l|l|l|}
\hline & & \multicolumn{3}{|l|}{ Groups } & Rate Difference \\
\hline & & & $\begin{array}{l}\text { Control Group } \\
\mathrm{N}=7\end{array}$ & $\begin{array}{l}\text { Group 1 } \\
\mathrm{N}=13\end{array}$ & $\begin{array}{l}\text { Group 2 } \\
\mathrm{N}=17\end{array}$ & \\
\hline \multirow{3}{*}{ FS production } & \multirow{3}{*}{ Correct FSs } & Number & 0 & 23 & 40 & \\
\cline { 3 - 8 } & \multirow{2}{*}{} & Rate & & 7,6 & 8 & 0,4 \\
\cline { 3 - 8 } & \multirow{2}{*}{ Attempts } & Number & 0 & 6 & 7 & \\
\cline { 3 - 8 } & & Rate & & 2 & 1,4 & $-0,6$ \\
\hline
\end{tabular}


pontaneous production of the nine target FSs was recorded for the Control Group in any of the writing activities in 2016 (column 4). Group 1 produced a total of 23 uncued grammatically and pragmatically correct uses across their three writing activities. Seven of the nine target sequences were used by 11 out of the 13 Group 1 participants. Participants in this group also produced six deviant FS instances (attempts). Twelve of the 17 participants in Group 2 used all nine target FSs, in 40 correct instances across their five writing activities. In Group 2, seven other productions were attempts that deviate from their standard use and form.

The rate of uncued FS production is almost identical for Groups 1 and 2, with 9.6 FSs produced on average per writing task for the first, and 9.4 for the second (Table 4). Chisquare analysis shows that the slight difference in the rate of correct FSs produced (with a slightly higher rate of correct forms produced by Group 2) is not in fact a significant difference in the proportions of "attempted" and correct forms by the two groups ( $\chi^{2}(2$, 76) $=0.11, p=.74)$. The production figures reported in Table 4 show that both Groups 1 and 2 showed evidence of productive FS learning and retention (as opposed to the Control Group), even eight weeks post intervention.

In a more in-depth analysis, we looked at learners' FS use per sequence across the different writing activities, and across time. First we compare correct FS use by Groups 1 and 2, followed by an analysis of the FS attempts by each group.

Figure 1 presents the use of the different target sequences (illustrated by different colours) by the members of Group 1, per writing activity. FS production is at its peak in the first data collection instance (Writing activity A) for this group, with 15 instances of five FSs. The number then decreases as time passes. In Writing activity B, a formulaic sequence not yet observed occurs, and remains through the third data collection period. The colours show that the same target FSs continue to occur. In Writing activity $\mathrm{C}$ no new target FSs are attempted, in addition to those already used in Writing activity A.

Figure 1. Spontaneous Use of FS by Group 1 per Writing Activity

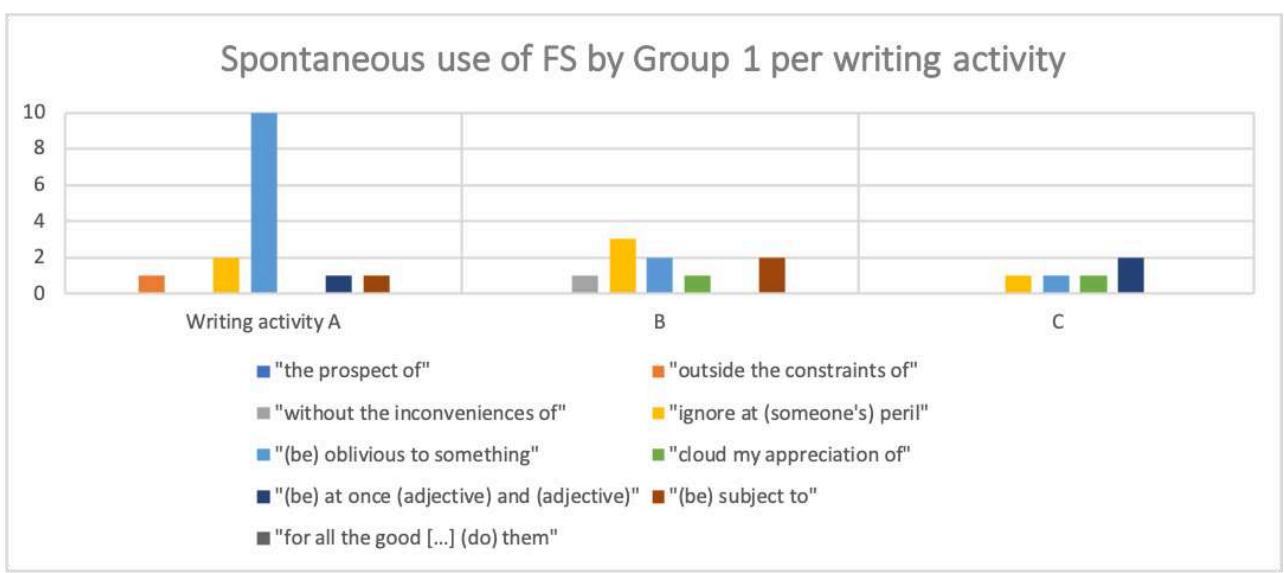

Single occurrences of the target FSs "outside the constraints of" and "without the inconveniences of" may illustrate a form of attrition, as described by Alharthi [2015] or simply the irrelevance of such expressions to the subsequent writing activities. The high frequency of "(be) oblivious to (something)" in Writing activity A may be due to 
the fact that this group had been working on the short story "Oblivious" (Cadwallader [2007]), which may have triggered the use of the FS containing this particular adjective.

An interesting observation concerning FS use in our written corpus concerns the distribution of sequences across time. In Group 1, there appear to be a few target sequences which are used one time only, with the exception of "(be) oblivious to something" and "ignore at (someone's) peril", which appear throughout all writing activities with a varying rate of frequency. There are individual occurrences of four other FSs: "outside the constraints of", "(be) at once (adjective) and (adjective)", "without the inconveniences of" and "(be) subject to". These results probably reflect individual learner's lexical preferences. One student in particular may have learnt one or two FSs and may have made consistent use of them throughout data collection; further analysis is needed to determine these individual preferences. As an illustration, examples (6), (7) and (8) show correct target FS use across instruments for some participants in Group 1:

(6) Not caring about the environment, being oblivious to what nature is trying to tell us through signs like natural disasters are some of the consequences. (Writing activity A LIiii2)

(7) Yet people drink liters and liters of alcohol ignoring at their peril how harmful this can be for their social relations. (Writing activity B Lliii14)

(8) The headline of the article means that experts are at once worried and surprised about the death of a large number of whales... (Writing activity $C$ Lliii18)

While (6) and (7) exemplify the use of the two most frequent FSs in Group 1, (8) shows a more infrequent FS (appearing only in Writing activity C) used correctly. In this respect, the use of "(be) at once (adjective) and (adjective)" triggered more deviant forms than correct uses, as we will see below.

Figure 2 presents FS production across writing activities for Group 2, and shows a different pattern of use and distribution across data collection, in comparison to Group 1 (Figure 1): there is a gradual increase which starts with limited FS use in Writing activity A. FS production then doubles for Writing activity B, and reaches a peak in activity $\mathrm{C}$, after which production of these forms decreases:

Figure 2. Spontaneous use of FS by Group 2 per writing activity

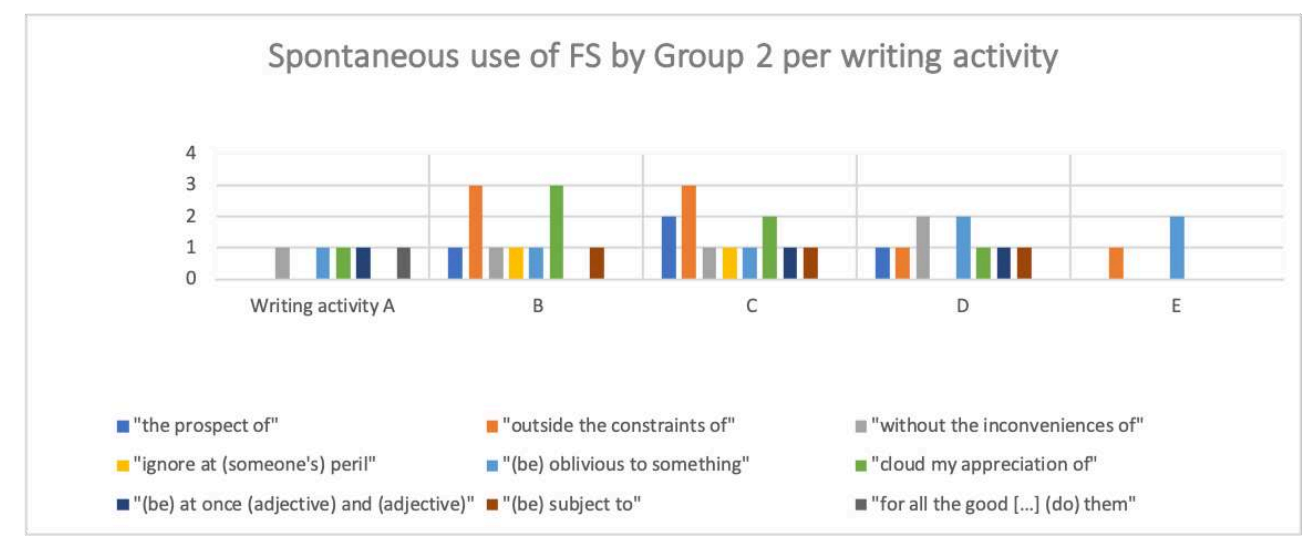

A detailed analysis of the target FSs produced by Group 2 indicates that, as in Group 1, "(be) oblivious to something" is used across all writing activities, albeit without the outstanding initial frequency found in Group 1 (possibly resulting from their reading 
assignments, as mentioned above). The only occurrence of "for all the good [...] (do) them" in the study is recorded by a participant in Group 2 and it appears only once, in the initial task, and then disappears. Instances of "outside the constraints of" appear first and frequently in Writing activity B, and occur again with less frequency until Writing activity E. The sequences "cloud my appreciation of" and "without the inconveniences of" appear throughout Writing activities A to D with varying degrees of frequency. The target FS "the prospect of" is used by writers in Group 2, whereas it is absent from the Group 1 texts. Again, these results could be attributed to inter-learner variation with respect to lexical choice. The fact that all nine target FSs have been used at some point in Group 2's writing activities - and only seven of them in Group 1 might indicate differing effects of the type of instruction and practice that each group received (or simply the fact that the Group 2 analyses include more written texts than for Group 1). The two dictogloss tasks completed by Group 2 may have offered participants a clearer example of FS use in a single unified text, while the variety of item contexts in the focus-on-form FS-oriented tasks completed by Group 1 may have led to a more disparate perception of FS meaning or use.

Examples 9-12 are taken from the Group 2 corpus, illustrating the use of the most frequent FSs across all five writing activities. Some of these target FSs coincide with those used by Group 1:

(9) Undoubtedly, this is a very dramatic problem that affects not only the children but also their parents by clouding their appreciation of this issue. (Writing activity A LIiii37)

(10) As I have tried to show throughout this work, innovative technologies have opened up the prospect of changes in medicine and our way of living. (Writing activity C LIiii27)

(11) A negative issue, on the contrary, should be that it makes us be oblivious to the ones that are closer to us, in a real situation. (Writing activity D LIiii30)

(12) In this way, the information can be easily accessible to the students outside the constraints of gadgetry and connectivity. (Writing activity E LIiii4)

Uncued production of FSs for both Groups 1 and 2 shows a positive impact of both instruction conditions on the acquisition of the target sequences, in comparison to the absence of spontaneous use of these forms in the Control Group's writing activities. In both experimental groups, long-term FS use can be attributed to controlled targeted instruction, since no further FS-focused input was provided (for example, in recycling tasks) post intervention. Furthermore, participants were not aware of which FSs were targeted, and unlike in many other FS-focused studies (Schmitt et al. [2004]), they were not asked to memorize, imitate or produce FS contexts for the data collection instruments.

One shared characteristic between Group 1 and Group 2 is the decrease in variety and number of instances of target FSs towards the end of the sixteen-week period of the study. Common to both experimental groups is deviant target use: Group 1 produced six grammatically incorrect and/or pragmatically inappropriate sentences, and Group 2 produced seven. A detailed analysis of the deviations from the standard sequences indicates that the same problems regarding the restrictions or patterns of use of each target FS seem to affect both groups (see Zinkgraf \& Verdú [2020] for a more detailed analysis of the type of deviant uses in Group 2). 

"outside the constraints of" are related to the spelling of the noun, which seems to be confused with the verb constrain. In erroneous use of the sequence "(be) at once (adjective) and (adjective)", both adjectives had a positive connotation (examples found in both groups). For the sequence "without the inconveniences of", the deviations are mostly pragmatic and semantic. Learners produced grammatically correct contexts for these sequences but there were certain elements that rendered their sentences unnatural and different from the contexts found in the reference materials consulted (dictionaries and corpora). An intentional meaning is conveyed in one of Group 1's deviant uses of "ignore at (someone's) own peril", while in another, part of the sequence (the verb) is missing. The expression "(be) oblivious to (something)" is used as if it were semantically intentional, an aspect which clearly goes against the meaning of the FS. The sequence "cloud (someone's) appreciation of" was semantically misused twice. Overall, similar factors seem to be responsible for the deviations in the attempts for both groups.

The dictogloss technique is astonishingly productive for the learners in Group 2, who produced target FSs spontaneously, at the same rate as learners who had completed far more form-focused activities of different types. Dictogloss probably reinforces the receptive knowledge of these complex language forms, which in turn may reinforce memorization, and recall in productive tasks. As suggested above, the dictogloss training also may help L2 learners understand the discursive function of formulaic language better than tasks that focus on specific expressions in limited stretches of discourse. These findings corroborate Lindstromberg et al. [2016], who also found positive effects of dictogloss on FS production.

The rate of spontaneous FS production in Groups 1 and 2 could also be due in part to individual learner preferences across data collection instances. Certain participants seem to have acquired specific FSs, which they use systematically across the essay writing tasks: participants Lliii4, Lliii9 and Lliii11 in Group 1, and LIiii30, Lliii33 and Lliii43 in Group 2. The total production of target FS by these three learners amounts to almost half of each group's total.

Our study spans a longer period of time than other studies gauging FS acquisition through writing tasks, like Jones \& Haywood [2004], Alhassan \& Wood [2015] and Peters \& Pauwels [2015]. Although these studies did not measure spontaneous production, the present study offers evidence of productive FS knowledge still available eight weeks after the treatment period is over for both treatments. Our results complement those of Janssens [2016], offering evidence of spontaneous production of target FSs by Group 2, eight weeks after the last dictogloss activity was completed. While Lindstromberg and colleagues [2016] and Janssens [2016] explored cued production no later than a week after task completion, the present study shows evidence of sustained spontaneous production of FSs in EFL.

Further evidence is available for this sustained effect since, in five successive essay writing tasks after week 16, six participants in Group 2 continued to use the six most frequent FSs in a total of 14 instances. After an academic winter recess of two months, however, Group 2's production of these target sequences decreased by two thirds, in comparison to their first term productions.

Even if these late instances may reflect individual learner processes and should not be taken to represent the whole population studied, they still illustrate active FS 
productive knowledge as late as 18 weeks post instruction - and therefore solid acquisition of these multiword units. Our findings shed new light on Alharthi's results [2015]: although some attrition is observed, through the gradual decrease of FS use for both of our learner groups, in this study we find evidence of meaning recall as late as eighteen weeks post FS-focused instruction in the case of Group 2 (these later longitudinal measures were not collected for Group 1). The data obtained through these writing tasks should be supplemented by targeted FS-production experiments, where variables are manipulated to measure changes in production, and particularly attrition in target FS knowledge (Eisenbeiss [2010: 11]).

\section{Conclusion} university learners' acquisition of nine pedagogically relevant formulaic sequences across different moments in time, measured longitudinally through participants' spontaneous FS use in their written production. Results show that 11 participants in Group 1 produced 23 instances of seven target FSs across three essay writing tasks, eight weeks after the treatment concluded. After Group 2's dictogloss sessions, a total of 40 target FSs were recorded in nine essay-writing tasks submitted by 13 participants at different stages of the study, some appearing even two months after the pedagogical intervention. Both conditions offer evidence of the positive impact of FS-focused explicit instruction on the development of FL learners' formulaic competence. For both Groups 1 and 2, a high degree of grammatical precision and pragmatic appropriacy is observed in the learners' productions, despite the occurrence of some deviant uses.

Dictogloss (the main technique in the treatment for Group 2) seems to encourage advanced university students' use of formulaic sequences in context, and promote retention in memory, since our data offers evidence of active productive knowledge of the target sequences around four months after the instruction period. This is the latest post-instruction measure recorded in FS studies to date. An adaptation of Wajnryb's [1990] dictogloss technique exposes students to contextualised FSs as whole units of meaning in the original text, and genuinely collaborative communication during text reconstruction seems to contribute to developing productive knowledge of these sequences and their retention over time.

Some implications for the use of dictogloss can be derived from this study. Since it appears to work as a facilitator of the kind of productive lexical knowledge referred to by Schmitt [2010] and Laufer [1997], we advocate its systematic inclusion in the language classroom, while further research might explore its application at different proficiency levels and in different types of EFL contexts. Dictogloss could also be exploited when teaching recurrent FSs in specific discourse genres, such as academic writing, or biographies. As Boers \& Lindstromberg have suggested [2012], the importance of developing foreign-language formulaic competence through explicit instruction cannot be stressed enough, for all educational settings. Of the different "pushed-output" procedures available in our language classrooms, dictogloss seems to be an interesting meaning-based tool that contributes to this aim effectively. 


\section{BIBLIOGRAPHY}

AITCHISON Jean, 1994, Words in the mind: An introduction to the mental lexicon, $2^{\text {nd }}$ edition, Oxford: Blackwell.

ALHARTHI Thamer, 2015, "Adding More Fuel to the Fire: A Study of Attrition in Formulaic Sequences by Adult Learners", Arab World English Journal (AWEJ), 6, 3, 230-243.

ALHASSAN Lina \& WoOD David, 2015, "The Effectiveness of Focused Instruction of Formulaic Sequences in Augmenting L2 Learners' Academic Writing Skills: A Quantitative Research Study", Journal of English for Academic Purposes, 17, 51-62.

BOERS Frank \& LINDSTROMBERG Seth, 2009, Optimizing a lexical approach to instructed second language acquisition, Palgrave Macmillan.

BOERS Frank \& LinDSTROMBERG Seth, 2012, "Experimental and intervention studies on FSs in a second language", Annual Review of Applied Linguistics, 32, 83-110.

Boers Frank, Eyckmans June, KAPPel Jenny, STENGers Helene \& DemeCHELEer Murielle, 2006, "Formulaic sequences and perceived oral proficiency: Putting a lexical approach to the test", Language Teaching Research, 10, 245-261.

CADWALLADER Gary, 2007, “Oblivious”, Smokelong Quarterly 17, http://www.smokelong.com/ oblivious/

CAPEL Annette \& SHARP Wendy, 2013 [2002], Objective Proficiency, Cambridge: CUP.

ConKLIN Kathy \& SCHMITT Norbert, 2008, "Formulaic sequences: Are they processed more quickly than non-formulaic language by native and nonnative speakers?", Applied Linguistics, 29, 72-89.

CONZETT Jane, 2000, "Integrating collocation into a reading and writing course", in LEWIS Michael (Ed.), Teaching collocation: further developments in the lexical approach, Hove: Language Teaching Publications, 70-87.

CowIE Anthony Paul, MACKIN Roland \& McCAIG Isabel R. (Eds.), 1998, The Oxford Dictionary of Current Idiomatic English, Oxford: Oxford University Press.

COXHEAD Averil, 2008, "Phraseology and English for academic purposes", in MEUNIER Fanny \& GRANGER Sylviane (Eds.), Phraseology in foreign language learning and teaching, Amsterdam: John Benjamins, 149-161.

CROW John, 1986. "Receptive vocabulary acquisition for reading comprehension", The Modern Language Journal, 70, 242-250.

DAVIES Mark. 2008-, The Corpus of Contemporary American English: 520 million words, 1990-present, http://corpus.byu.edu/coca/.

Doughty Catherine \& WiLliams Jessica, 1998, "Pedagogical Choices in Focus on Form", in DoughTY Catherine \& Williams Jessica (Eds.), Focus on Form in Classroom Second Language Acquisition, Cambridge: Cambridge University Press, 197-260.

EISENBEISS Sonya, 2010, "Production methods in language acquisition research", in BLOM, Elma \& UNSWORTH Sharon (Eds.), Experimental Methods in Language Acquisition Research, Amsterdam: John Benjamins Publishing Company, 11-34. 
EYCKMANS June, 2007, “Taking SLA research to interpreting: does knowledge of phrases foster fluency?", in BOERS Frank, DARQUENNES Jeroen \& TEMMERMAN Rita (Eds.), Multilingualism and Applied Comparative Linguistics, 1: pedagogical perspectives, Cambridge: Cambridge Scholar Publishing, 89-105.

GHEITASI Parvin, 2017, Say it fast, fluent and flawless: formulaicity in the oral language production of young foreign language learners, Unpublished doctoral dissertation, Umeå University, Faculty of Arts, Department of Language Studies.

GREAVES Chris \& WARREN Martin, 2010, "What can a corpus tell us about multi-word units?", in o'KEEFFE Anne \& MCCARTHY Michael (Eds.), The Routledge Handbook of Corpus Linguistics, London: Routledge, 212-226.

JANSSENS Hanna, 2016, Using the dictogloss procedure to improve the retention and use of L2 academic English formulaic sequences, Universiteit Gent, https://lib.ugent.be/.../

RUG01-002271689_2016_0001_AC.pdf

JONES Martha \& HAYWOOD Sandra, 2004. "Facilitating the acquisition of FSs", in SCHMITT Norbert (Ed.), Formulaic sequences, Philadelphia: John Benjamins Publishing, 269-300.

LAUFER Batia, 1997, “What's in a word that makes it hard or easy? Intralexical factors affecting vocabulary acquisition", in SCHMITT Norbert \& MCCARTHY Michael (Eds.), Vocabulary Description, Acquisition and Pedagogy, Cambridge, Cambridge University Press, 140-155.

LE-THI Duyen, RODGERS Michael P. H. \& PELLICER-SÁNCHEZ Ana, 2017, “Teaching Formulaic Sequences in an English-Language Class: The Effects of Explicit Instruction versus Coursebook Instruction", TESL Canada Journal, 34, 3, 111-139.

LEWIS Margareta, 2009, The Idiom Principle in L2 English: Assessing elusive formulaic sequences as indicators of idiomaticity, fluency and proficiency, Saarbrücken: VDM Verlag Dr. Müller.

LEWIS Michael, 1997, Implementing the Lexical Approach, Language Teaching Publications.

LI Jie \& SCHMITT Norbert, 2010, "The development of collocation use in academic texts by advanced L2 learners: A multiple case study approach", in wood David (Ed.), Perspectives on formulaic language: Acquisition and communication, New York, NY: Continuum, 22-46.

LINDSTROMBERG Seth \& BOERS Frank, 2008, Teaching Chunks of Language. From noticing to remembering, Helbling Languages.

LINDSTROMBERG Seth, EYCKMANS June \& CONNABEER Rachel, 2016, “A modified dictogloss for helping learners remember L2 academic English formulaic sequences for use in later writing”, English for Specific Purposes, 41, 12-21.

MUELLER Charles, 2017, "Maturational age effects on the status and role of formulaic sequences in first and second language learning", The Bulletin of the Faculty of Humanities, Fuji Women's University, 54, 1-55.

PELLICER-SÁNCHEZ Ana \& BOERS Seth, 2019, "Pedagogical Approaches to the Teaching and Learning of Formulaic Language", in SIYANOVA-CHANTURIA Anna \& PELLICER-SÁNCHEZ Ana (Eds.), Understanding formulaic language. a second language acquisition perspective, New York: Routledge, 153-173.

PETERS Elke \& PAUWELS Paul, 2015, "Learning academic formulaic sequences", Journal of English for Academic Purposes 20, 28-39.

ScHмITT Norbert, 2010, Researching Vocabulary: a Vocabulary Research Manual, London: Palgrave Macmillan. 
SCHMITT Norbert, 2014, "Size and depth of vocabulary knowledge: What the research shows", Language Learning, 64, 913-951.

SCHMITT Norbert, DÖRNYEI, Zoltán, ADOLPHS Svenja \& DUROW Valerie, 2004, “Knowledge and acquisition of formulaic sequences: A longitudinal study", in schмITT Norbert (Ed.), Formulaic sequences: Acquisition, processing, and use, Amsterdam: John Benjamins, 55-86.

SELIVAN Leo, 2018, Lexical Grammar: Activities for Teaching Chunks and Exploring Patterns, Cambridge: Cambridge University Press.

STENGERS Helene, 2009, The Idiom Principle put to the test: an exercise in comparative applied linguistics, Unpublished PhD Dissertation, Free University Brussels.

THORNBURY Scott, 2019, "Learning language in chunks", Part of the Cambridge Papers in ELT series [pdf], Cambridge: Cambridge University Press

TIMMIS Ivor, 2015, Corpus linguistics for ELT: Research and practice, New York: Routledge.

VASILJEVIC Zorana, 2010, "Dictogloss as an Interactive Method of Teaching Listening

Comprehension to L2 Learners", Canadian Center of Science and Education - English Language

Teaching, 3, 1, 41-52.

WAJNRYB Ruth, 1990, Grammar dictation, Oxford: OUP.

WIKTORSSON Maria, 2003, Learning Idiomaticity: A corpus-based study of idiomatic expressions in learners' written production, PhD Thesis (Manuscript), Lund University.

wooD David, 2009, "Effects of focused instruction of formulaic sequences on fluent expression in second language narratives: A case study", Canadian Journal of Applied Linguistics/Revue Canadienne de Linguistique Appliquée, 12.

wooD David (Ed.), 2010, Perspectives in formulaic language: Acquisition and communication, New York: Continuum Books.

WRAY Alison \& FITZPATRICK Tess, 2008, “Why can't you just leave it alone? Deviations from memorized language as a gauge of nativelike competence, in MEUNIER Fanny \& GRANGER Sylviane (Eds.), Phraseology in Foreign Language Learning and Teaching, Amsterdam: Philadelphia: John Benjamins Press, 123-148.

WRAY Alison, 2002, Formulaic language and the lexicon, Cambridge: CUP.

WULFF Stefanie, 2019, “Acquisition of formulaic language from a usage-based perspective”, in SIYANOVA-CHANTURIA Anna \& PELLICER-SANCHEZ Ana (Eds.), Understanding formulaic language. a second language acquisition perspective, New York: Routledge, 19-37.

ZINKGRAF Magdalena \& VERDÚ María Angélica, 2020, “El dictogloss: una herramienta pedagógica que fomenta el uso productivo de vocabulario en una lengua extranjera", in RIESTRA Dora, PEREYRA Verónica, GOICOECHEA María Victoria \& LASOTA Paz Cecilia (comp.), Sextas Jornadas Internacionales de Investigación y Prácticas en Didáctica de las lenguas y las literaturas, Viedma: Universidad Nacional de Río Negro, 1065-1077, http://www.editorial.unrn.edu.ar/media/data/otros/ VI_Jornadas_didactica_lengua_UNRN.pdf

\section{APPENDIXES}

Appendix A: Dictogloss, text 1 
We had been dreaming with a trip abroad together for some time. The prospect of visiting New York had always attracted us all. We started planning it for the winter holidays, when we would be able to tour around different places outside the constraints of time: we had two weeks off work and we were heading for the US. We organized the trip around the main sights we wanted to visit, without the inconvenience of hiring a guide or putting up with loud tourists. One of the most important highlights was our late evening in Harlem, even when we ignored at our peril the taxi-driver's warnings as to the time of day we had chosen. Oblivious to what previous tourists had advised us as regards paying extra for the Empire State Building Express ticket, we did not allow the three-hour queueing to cloud our appreciation of the breathtaking views from the rooftop. The enchanting atmosphere at Union Square Market proved to be at once local and global, with smells and flavours that any customer, even those from around the world, would find attractive. The only downside to the trip was the fact that we were subject to delaying security checks. We were so worried we would not get in time for the domestic flight to Neuquén... For all the good that did us! The plane broke down and we had to wait two hours to board it.

\section{Appendix B: Dictogloss, text 2}

At the gym, we are subject to some kind of collective euphoria about our dancing lessons. Last year, however, they were abruptly interrupted in November when our teacher had a car accident. Although he usually ignored the need for a seatbelt at his peril, fortunately he had been wearing it that day. We were oblivious to the seriousness of the injuries he had suffered. When we found out about his health, at first we were worried, but then, with time, the prospect of not dancing during three months became devastating. As a group, we thought that during the summer holidays we would be able to organize home-taught lessons outside the constraints of time: most of us had a lot of free time. But it soon became clear this would be difficult. At the gym, they set up new lessons with another teacher. For all the good it did! The fact that this new instructor had a completely different teaching style clouded our appreciation of these lessons: she was at once strict and motivating, but we just wanted our teacher back! By February our teacher recovered and we started attending his lessons without the inconvenience of having to adapt to someone else.

\section{Appendix C: Dictogloss Task Description}

In the dictogloss procedure (Wajnryb, [1990: 5/6]),

- The teacher reads a short text once at normal speed. In this first instance, learners listen only.

- While listening to the text a second time, students note down words and phrases in the passage.

- After these readings, they are invited to reconstruct the text in small groups based on the notes they took and what each one can contribute according to what they remember. The focus is on conveying the same meaning as the initial text.

- Each of the versions produced by the groups is analysed and compared during a whole class discussion, where all reconstructions are shared on a screen for everybody to see. 
- Each of the groups polish their texts in the light of this collaborative discussion to produce their final version.

\section{NOTES}

1. Wood [2009:39] offers the term unités de langue formulaïques in the French abstract for the article "Effects of focused instruction of formulaic sequences on fluent expression in second language narratives: A case study"and Le-Thi, Rodgers \& Pellicer-Sánchez [2017: 111] use formules as a French equivalent for this same linguistic feature.

2. Both explicit-instruction treatments evinced significantly higher recall rates than the Control Group and Group 1 significantly outperformed Group 2 in all posttests.

3. In Argentina, teacher-training programmes typically combine a major in English, to guarantee learners achieve a C1-C2 (CEFR) proficiency level in the language they will teach, and a teachertraining module. The whole course lasts four years.

4. To some native speakers one or two of these phrases, like "(be) at once (adjective) and (adjective)", may appear as non-formulaic. However, evidence in COCA (Davies [2008-]) in terms of its raw frequency (787) and a separate entry with a special meaning for this phrase (Entry 2) in dictionaries like Macmillan Dictionary ( https://www.macmillandictionary.com/dictionary/ british/at-once) indicate that they all are formulaic in nature (Wray [2008]).

5. Participants are identified with a code such as Lliii30, where Lliii corresponds to the course where the treatment took place and 30 indicates participant number. Control group participants were coded as LIiiiiC1 to LliiiC10.

\section{ABSTRACTS}

Corpus studies into the nature of language and the interrelationship between grammar and lexis have highlighted the pervasiveness of recurrent strings of words essential to the construction of meaning which Wray [2002: 9] has named "formulaic sequences" (FS). Research by Boers et al [2006], Eyckmans [2007], Stengers [2009] and Wray \& Fitzpatrick [2008] suggests that good command of these phrases in the foreign language $(\mathrm{FL})$, of their typical occurrence and of their use restrictions contributes to learners' fluency, and is taken as evidence of a high level of proficiency. Boers \& Lindstromberg [2012] argue that explicit FS instruction accompanied by awareness-raising tasks yield significant learning gains, especially in FL contexts. As a pushedoutput procedure, Wajnryb's dictogloss technique [1990] has recently been adapted in FS-focused instruction studies like those of Janssens [2016] and Lindstromberg, Eyckmans \& Connabeer [2016]. In similar fashion, we designed an experimental study for the teaching of nine pedagogically relevant sequences with Spanish-L1 EFL university learners. Two types of treatment were implemented with a focus on the target FSs' meanings, forms and uses with two naturally-occurring learner groups (Group 1, N=13, and Group 2, N=17), whose performance was compared to that of a control group $(\mathrm{N}=7)$. Group 1 completed a set of Focus-on-Form activities [Doughty \& Williams 1998], while Group 2 carried out two sessions of FS-oriented dictogloss. Results show that learners in Group 2 produced 40 instances of the target FS in five essay-writing tasks at different stages of the study and as late as a month and a half post intervention. By contrast, Group 1 produced 23 instances of seven target FSs across three essay writing tasks, six 
weeks after treatment. These findings indicate that dictogloss seems to reinforce advanced students' familiarization with target FS in context, and FS memory retention over time. Based on the descriptive analysis of uncued target FSs produced by learners in their written production tasks, the possible contributions of dictogloss to long-term FS acquisition are discussed.

Au cours des dernières décennies, des études de corpus sur la nature du langage et l'interaction entre grammaire et lexique ont mis en évidence l'ubiquité des chaînes de mots récurrentes essentielles à la construction du sens, appelées par Wray [2002:9] «formulaic sequences ». Les recherches menées par Boers et al. [2006], Eyckmans [2007], Stengers [2009] et Wray \& Fitzpatrick [2008] suggèrent qu'une bonne gestion de ces phrases dans une langue étrangère (LE), de leurs usages typiques et des restrictions qui les régissent, contribue à la maîtrise orale des étudiants et témoigne d'un haut niveau de compétence. Boers \& Lindstromberg [2012] soutiennent que l'enseignement explicite de formulaic sequences ${ }^{1}$ (désormais FS) accompagné de tâches de sensibilisation à leur utilisation génère des avancées significatives dans l'apprentissage des langues étrangères en contexte éducatif. En tant que tâche de production induite, le dictogloss (Wajnryb [1990]) a été adapté dans des études portant sur l'acquisition des FS en contexte instructionnel, comme c'est le cas chez Janssens [2016] et Lindstromberg, Eyckmans \& Connabeer [2016]. Dans ce même but, nous avons préparé une étude expérimentale pour l'enseignement de neuf SF dans le cadre de l'enseignement de l'anglais langue étrangère à des étudiants à l'université ayant l'espagnol comme L1. Deux types d'enseignement ont été mis en œuvre dans deux groupes expérimentaux naturels. Le Groupe 1 a réalisé une séquence d'activités favorisant l'attention au sens, à la forme et à l'utilisation des séquences selon leurs restrictions d'usage (Focus on Form, [Doughty\& Williams 1998]). Le Groupe 2 a travaillé avec le dictogloss dans deux séquences d'apprentissage différentes. Les résultats de deux interventions didactiques ont été comparés aux performances d'un groupe témoin, ayant travaillé seulement sur la signification et la forme de FS, sans avoir réalisé des activités d'application. Cet article analyse l'utilisation spontanée de neuf FS sélectionnées dans la production écrite des trois groupes d'étudiants (Groupes 1, 2 et témoin). Dans le Groupe 2, un total de 40 utilisations de toutes les FS a été enregistré dans cinq essais écrits à différents moments de l'étude, jusqu'à deux mois après la fin de la période d'enseignement. En revanche, le Groupe 1 a produit 23 instances de sept FS, seulement dans trois essais, trois semaines après la fin du traitement. Ces résultats semblent indiquer que le dictogloss favorise la familiarisation des élèves avec les FS en contexte, et contribue à renforcer leur mémorisation. Les avantages possibles du dictogloss pour l'acquisition à long terme de l'anglais langue étrangère seront abordés dans le cadre de cet article.

\section{INDEX}

Mots-clés: acquisition lexicale en langue étrangère, formulaic sequences, anglais universitaire, dictogloss, enseignement explicite, production écrite spontanée

Keywords: EFL vocabulary acquisition, formulaic sequences, advanced university learners, dictogloss, explicit FS instruction, uncued written production

\section{AUTHORS}

\section{MAGDALENA ZINKGRAF}

Universidad Nacional del Comahue, Argentina maguizinkgraf@gmail.com 


\section{MARÍA ANGÉLICA VERDÚ}

Universidad Nacional del Comahue, Argentina angie_verdu@hotmail.com 